\title{
Fermentation times and feed additives improve the quality of olive bagasse silage
}

\section{Aditivos alimentares e tempos de fermentação melhoram a qualidade de silagens de bagaço de azeitona}

\author{
Neliton Flores Kasper ${ }^{1 *}$; Leonardo Ereno Tadielo ${ }^{2}$; Othon Dalla Colletta \\ Altermann $^{1}$; Fabiane Quevedo da Rosa ${ }^{3}$; Antônio Dias Echeverria ${ }^{4}$; Eduardo \\ Bohrer de Azevedo ${ }^{5}$ : Luciane Rumpel Segabinazzi ${ }^{6}$; Deise Dalazen Castagnara ${ }^{7}$
}

\begin{abstract}
This research aimed to measure the microbiological, chemical composition profile and fermentative characteristics during storage of fresh olive bagasse, in natura and incorporated with corn, soybean and rice brans, respectively. The experimental design was completely randomized, with the plots constituting the four main treatments (olive bagasse in natura or with added corn, soybean and rice brans, respectively), and the subplots allocated the three sampling times, which corresponded to time zero (at the ensilage moment) and 28 and 56 days of ensilage. The fermentative characteristics (dry matter content $[\mathrm{DM}], \mathrm{pH}$ and ammoniacal nitrogen $\left[\mathrm{NH}_{3}-\mathrm{N}\right]$, microbiological profile (populations of filamentous fungi, lactic acid bacteria, enterobacteria and Clostridia) and chemical composition profile (mineral matter, organic matter, crude protein [CP], ether extract, neutral detergent fiber, acid detergent fiber, lignin, cellulose and hemicellulose) were determined. The corn grain and rice meal treatments, which demonstrated $\mathrm{pH} 4.08$ and 3.96 at 28 days of fermentation, respectively, provided the best fermentation profile. After storage for 56 days, the samples with added soybean and rice meal reached the highest levels of CP (166.15 and $\left.93.78 \mathrm{~g} \mathrm{~kg}^{-1} \mathrm{DM}\right)$, respectively. Increasing the storage period reduced the $\mathrm{pH}$ of the obtained silages but increased the losses of $\mathrm{DM}, \mathrm{NH}_{3}-\mathrm{N}$ and contributed to the losses of some nutrients. Rice meal and corn grain have been recommended to be used as additives in olive bagasse storage. However, the choice of additives studied is dependent on their commercial availability in each region.
\end{abstract}

Key words: Cellulose. Crude protein. Microbiology. Nutritional value. Olea europaea.

1 Discentes, Curso de Medicina Veterinária, Universidade Federal do Pampa, UNIPAMPA, Uruguaiana, RS, Brasil. E-mail: nelitonfloreskasper@hotmail.com; othon_altermann@hotmail.com

2 Discentes, Programa de Pós Graduação em Ciência Animal da Universidade Federal do Paraná, UFPR, Setor Palotina, PR, Brasil. E-mail: leonardotadielo@gmail.com

3 Discente, Doutorado do Programa em Ciência Animal, Universidade Federal do Rio Grande do Sul, UFRGS, Porto Alegre, RS, Brasil. E-mail: fabiq.rosa@yahoo.com.br

4 Técnico de Laboratório/Agropecuário, FURG, São Lourenço do Sul, RS, Brasil. E-mail: antonioecheverria@furg.br

5 Prof. Dr., Curso de Agronomia, Universidade Federal do Pampa, UNIPAMPA, Itaqui, RS, Brasil. E-mail: eduardoazevedo@, unipampa.edu.br

6 Prof $^{\mathrm{a}}$ Dr $^{\mathrm{a}}$, Curso de Zootecnia, UniversidadeFederal do Pampa, UNIPAMPA, Dom Pedrito, RS, Brasil.E-mail:1ucianesegabinazzi@ unipampa.edu.br

7 Prof $^{\mathrm{a}}$ Dra ${ }^{\mathrm{a}}$, Curso de Medicina Veterinária, Universidade Federal do Pampa, UNIPAMPA, Uruguaiana, RS, Brasil. E-mail: deisecastagnara@yahoo.com.br

* Author for correspondence 


\section{Resumo}

Objetivou-se estudar a composição bromatológica, perfil microbiológico e características fermentativas da silagem de bagaço de azeitona in natura e aditivada com farelos de milho, soja e arroz em diferentes tempos de amostragem. $\mathrm{O}$ delineamento experimental utilizado foi completamente casualizado em arranjo de parcelas subdivididas no tempo $4 \times 3$ com cinco repetições. Nas parcelas foram alocados os tratamentos principais, constituídos do bagaço de azeitona in natura ou adicionado com farelo de milho, soja e arroz, e nas subparcelas os tempos de amostragem, que correspondem ao tempo zero (momento da ensilagem) e aos 28 e 56 dias de fermentação. As características fermentativas foram estudadas pela determinação dos conteúdos de matéria seca (MS), $\mathrm{pH}$ e nitrogênio amoniacal $\left(\mathrm{N}_{-} \mathrm{NH}_{3}\right)$. Para determinação do perfil microbiológico foram estudadas as populações de fungos filamentosos, bactérias ácido láticas, enterobactérias e clostrídeos. $\mathrm{Na}$ avaliação do perfil bromatológico determinou-se os conteúdos de matéria mineral $(\mathrm{MM})$, matéria orgânica $(\mathrm{MO})$, proteína bruta $(\mathrm{PB})$, extrato etéreo $(\mathrm{EE})$, fibra em detergente neutro (FDN), fibra em detergente ácido (FDA), lignina, celulose e hemicelulose. $\mathrm{O}$ uso dos farelos de milho e arroz proporcionou melhores características fermentativas as silagens, estes tratamentos apresentaram pH de 4,08 e 3,96 aos 28 dias de fermentação, respectivamente. Aos 56 dias de armazenamento os tratamentos adicionados com farelos de soja e arroz demostrataram os melhores níveis de PB (116,15 g/kg e 93,78 g/kg MS), respectivamente. O aumento do período de armazenamento reduziu os teores de $\mathrm{pH}$ das silagens obtidas, no entanto, aumentou as perdas de matéria seca, teores de nitrogênio amoniacal e contribuiu com perdas de alguns nutrientes. Os farelos de arroz e milho são recomendados para serem utilizados como aditivos na silagem de bagaço de azeitona, porém, a escolha dos aditivos estudados está condicionada a disponibilidade comercial de cada região.

Palavras-chave: Celulose. Microbiologia. Olea europaea. Proteína bruta. Valor nutricional.

\section{Introduction}

Olive (Olea europaea) cultivation is ideally adapted to regions having a Mediterranean type of climate, typified by hot, dry summers, relatively cool winters with seldom frost and average annual precipitation of around $800 \mathrm{~mm}$ (ABAZI et al., 2013). During two-stage olive processing, a large volume of residues is produced, amounting to about $800 \mathrm{~kg}$ of semi-solid waste (termed alpeorujo) per $1000 \mathrm{~kg}$ of processed olives (MOLINA-ALCAIDE; YAÑEZ-RUIZ, 2008). Owing to its environmental contamination potential, the industry incurs high costs associated with the treatment and adequate disposal of this residue (WEINBERG et al., 2008). Approximately $300 \mathrm{~kg}$ of the waste generated is equivalent to a semi-solid waste, called olive bagasse (NIAOUNAKIS; HALVADAKIS, 2006), which may have the potential for use in animal feed, especially for ruminants (WEINBERG et al., 2008).

The production of olive bagasse is seasonal, corroborating with the time of fruit production and olive oil extraction. Though olive cake presents a high amount of energy and fiber (CHIOFALO et al., 2004), its high polyphenol and ether extract (EE) contents and low digestibility justify the use of alternative foods that improve the composition of this material. The proportional dilution of the polyphenols and EE may favor the formation of microbial protein and a better utilization by the animals at the digestive level.

The possibility of agro-industrial co-products in animal feeding use reduces the demand for optimal feed and contributes to global food security (NASOPOULOU; ZABETAKIS, 2013). However, as mentioned above, olive bagasse presents seasonal production and, besides, has already been considered of low nutritional value, regarding energy and protein, compared with that of other culture residues (NASOPOULOU; ZABETAKIS, 2013).

Among the options for the conservation of these co-products used as animal feed, is ensiling. The main principles of this preservation technique are an anaerobic environment and a low $\mathrm{pH}$, with lactic 
acid bacteria dominating the fermentation. Silage is accessible and economical (SANSOUCY et al., 1985) when used for conservation of agro-industry by-products.

However, for the efficient fermentative process, the material to be ensiled needs to have some characteristics, such as an adequate amount of soluble carbohydrates, low buffering capacity and a dry matter (DM) content between 300 to $350 \mathrm{~g} \mathrm{~kg}^{-1}$ (McDONALD et al., 1991). These characteristics, which ensure the achievement of desirable fermentation and conservation standards throughout storage, are not inherent in olive bagasse (SANSOUCY et al., 1985) but can result from the use of food additives, such as brans (NERES et al., 2013). While some by-products have the potential for use in ruminant feed, the nutritional value of these by-products is dependent on the biochemical and dynamic processes of interaction that occur during the storing conditions (AZEVÊDO et al., 2011).

This paper aimed to measure the fermentative, microbiological and bromatological profile of the silage from fresh olive bagasse incorporated with additives (corn, soybean and rice brans, respectively), at different storage periods.

\section{Material and Methods}

The experiment was carried out at Tecnolivas ${ }^{\circledR}$ Indústria/Pomares, located in the municipality of Caçapava do Sul, Rio Grande do Sul, Brazil, and at the Animal Nutrition Laboratory of Unipampa, Uruguaiana Campus (latitude: 29 45'17' S, longitude: $57^{\circ} 05^{\prime} 18^{\prime}$ W, $66 \mathrm{~m}$ altitude), Rio Grande do Sul, Brazil.

The design was completely randomized, with the plots constituting the four main treatments (olive bagasse in natura or with added corn grain, soybean meal and rice meal, respectively), and the subplots allocated the three sampling times, which corresponded to time zero (at the ensilage moment) and 28 and 56 days of storage.

To achieve silages with a DM of $330 \mathrm{~g} \mathrm{~kg}^{-1}$, the mixtures were prepared based on the natural matter in the proportion of 93 parts of olive bagasse in natura to seven parts of additives, considering the DM contents determined in an air-forced oven (Table 1). This choice of DM content lies within the range recommended by McDonald et al. (1991) for silage fermentations, which is between 300 and 350 $\mathrm{g} \mathrm{kg}^{-1} \mathrm{DM}$.

Table 1. Composition of olive bagasse in natura and the additives used in the treatments.

\begin{tabular}{lcccc}
\hline \multirow{2}{*}{ Variable } & \multirow{2}{*}{ In natura bagasse } & \multicolumn{3}{c}{ Additives used in the composition of silages } \\
\cline { 3 - 4 } Dry matter & & Rice meal & Soybean meal & Corn grain \\
Mineral matter & 289.53 & 862.92 & 833.50 & 886.33 \\
Organic matter & 32.60 & 109.94 & 67.91 & 11.56 \\
Crude protein & 965.42 & 890.12 & 932.13 & 988.53 \\
Neutral detergent fiber & 50.54 & 126.33 & 450.32 & 88.74 \\
Acid detergent fiber & 602.51 & 248.22 & 270.66 & 99.95 \\
Ether extract & 562.41 & 137.63 & 122.86 & 54.43 \\
Lignin & 242.72 & 183.21 & 33.97 & 41.43 \\
Total carbohydrate & 355.75 & 53.87 & 23.04 & 29.12 \\
Non-fibrous carbohydrate & 672.26 & 580.63 & 447.96 & 858.45 \\
Fibrous carbohydrate & 120.93 & 332.43 & 177.34 & 758.52 \\
\hline
\end{tabular}

Dry matter $\left(\mathrm{g} \mathrm{kg}^{-1}\right)$; all other variables are expressed as $\mathrm{g} \mathrm{kg}^{-1} \mathrm{DM}$. 
The mixtures were homogenized manually and conditioned in experimental silos made with polyvinyl chloride pipes of dimensions $50 \mathrm{~cm}$ in height and $10 \mathrm{~cm}$ in diameter. Each silo contained $3,900 \mathrm{~kg}$ of the blend, equivalent to a silage density of $900 \mathrm{~kg} \mathrm{~m}^{-3}$. The silos were sealed with caps equipped with Bunsen-type valves, for the free escape of the gases, and fixed with the aid of adhesive tape. For the drainage of the effluent produced, 0.5 $\mathrm{kg}$ of dry, autoclaved sand, insulated by a cotton cloth, was placed in the bottom of each silo. Sixty experimental silos were used, due to the number of treatments (four), sampling times (three) and the number of replicates (five) of the experiment.

After the fermentation periods stipulated (28 and 56 days), the silos were opened, and the upper and lower portion of each silo $(5 \mathrm{~cm})$ was discarded. The remaining silage was homogenized and sampled, for analysis of the fermentative characteristics, microbiological profile and chemical composition.

The fermentative characteristics included DM, pH and, also, ammoniacal nitrogen, which was determined as the fraction of the total nitrogen $\left(\mathrm{NH}_{3}-\mathrm{N} / \mathrm{TN}\right)$ in the ensilage, at 28 and 56 days of fermentation. The DM was determined gravimetrically on samples of $300 \mathrm{~g}$ collected from each repetition, by drying in an oven with forced air circulation at $55^{\circ} \mathrm{C}$ for $72 \mathrm{~h}$. Measurements of the $\mathrm{pH}$ (SILVA; QUEIROZ, 2009) and $\mathrm{NH}_{3}-\mathrm{N}$ (BOLSEN et al., 1992) were taken from $50 \mathrm{~g}$ per replicate.

To identify the microbial profiles (SILVA et al., 2007), the collected samples were homogenized. A stock solution of $10 \mathrm{~g}$ to $90 \mathrm{~mL}$ of peptone water was serially diluted to $10^{1}-10^{8}$ and inoculated into selective culture medium to determine the colonyforming units (CFU) per gram of DM. The four media used, and the incubation conditions were potato dextrose agar (filamentous fungi and yeasts) at room temperature for 5 to 7 days; de ManRogosa-Sharpe (MRS) broth (lactic acid bacteria [LAB]) at $35^{\circ} \mathrm{C}$ for $48 \mathrm{~h}$; violet red bile agar (Oxford) (Enterobacteriaceae) at $35{ }^{\circ} \mathrm{C}$ for $72 \mathrm{~h}$, and reinforced clostridial agar (Clostridia) at $35^{\circ} \mathrm{C}$ for $72 \mathrm{~h}$ in anaerobic medium. Only dilutions that yielded 30-300 CFU per Petri dish were counted, and the results were expressed as $\log _{10} \mathrm{CFU} \mathrm{g}^{-1} \mathrm{DM}$ (McDONALD et al., 1991).

After oven-drying $\left(55^{\circ} \mathrm{C}\right.$ for $\left.72 \mathrm{~h}\right)$ the samples were ground in a Willey Mill (stainless-steel $1 \mathrm{~mm}$ mesh sieve), to determine the chemical composition: $\mathrm{DM}$ correction at $105{ }^{\circ} \mathrm{C}$, and the contents of mineral matter (MM), crude protein (CP), EE (SILVA; QUEIROZ, 2009), neutral detergent fiber (NDF), acid detergent fiber (ADF), lignin, cellulose and hemicellulose (VAN SOEST et al., 1991).

The data were submitted to analysis of variance. If significant, the mean values were compared by Tukey's test (5\%), with the adoption of complex variance, due to subdivided plots. When the interaction of the factors evaluated (treatments $\times$ sampling times) was not significant, only the mean of the individual factors was used to compare the results. All statistical analyses were performed using the statistical program Sisvar (FERREIRA, 2011).

\section{Results and Discussion}

There were significant differences in the DM, $\mathrm{pH}$ and $\mathrm{NH}_{3}-\mathrm{N}$ losses of the olive silage with food additives, whereas the DM during storage was not affected by the studied sources of variation (Table 2). At 28 days of fermentation, the highest losses of DM were observed in the storage of olive bagasse with added rice meal while at 56 days of fermentation, the addition of soybean meal resulted in higher losses of DM in the silages (Table 2). The additive-free bagasse presented the least DM loss at 56 days of fermentation, in contrast to the bagasse with added soybean meal. The remaining silages maintained consistent losses at the two fermentation periods (Table 2).

The use of additives increased the DM, thus, favoring the fermentation process (Table 2). Souza et al. (2012) demonstrated the efficiency of ensilage for the conservation of wet brewery residue, which has a moisture content higher than olive bagasse. Likewise, Gonçalves et al. (2014) confirmed the feasibility of the ensilage process in preserving cassava starch residue, thereby supporting the 
hypothesis that the method of conservation of the olive bagasse used in the present study offers

beneficial conditions for maintaining the quality of different sub-products.

Table 2. Dry matter, dry matter losses, $\mathrm{pH}$ and ammoniacal nitrogen $\left(\mathrm{NH}_{3}-\mathrm{N}\right)$ of olive bagasse silages with feed additives at ensilage and 28 and 56 days of storage.

\begin{tabular}{|c|c|c|c|c|c|c|c|c|}
\hline \multirow{2}{*}{ Treatments } & Ensilage & 28 days & 56 days & Average & Ensilage & 28 days & 56 days & Average \\
\hline & \multicolumn{4}{|c|}{ Dry matter $\left(\mathrm{g} \mathrm{kg}^{-1}\right)$} & \multicolumn{4}{|c|}{ Dry matter losses (\%) } \\
\hline Bagasse & 299.09 & 315.35 & 315.87 & $310.10 \mathrm{~d}$ & - & $4.70 \mathrm{bA}$ & $2.50 \mathrm{cB}$ & 3.60 \\
\hline Bagasse + corn & 308.60 & 375.42 & 365.65 & $349.89 b$ & - & $4.71 \mathrm{bA}$ & $5.51 \mathrm{bA}$ & 5.11 \\
\hline Bagasse+soybean & 316.85 & 338.97 & 346.31 & $334.04 \mathrm{c}$ & - & $5.40 \mathrm{abB}$ & $11.12 \mathrm{aA}$ & 8.26 \\
\hline Bagasse+rice & 349.90 & 394.84 & 382.73 & $375.82 \mathrm{a}$ & - & $6.32 \mathrm{aA}$ & $6.21 \mathrm{bA}$ & 6.27 \\
\hline Average & 318.61B & $356.15 \mathrm{~A}$ & $352.64 \mathrm{~A}$ & & - & 0.53 & 0.63 & \\
\hline CV1 $(\%)$ & \multicolumn{4}{|c|}{32.40} & \multicolumn{4}{|c|}{58.18} \\
\hline \multirow[t]{2}{*}{ CV2 $(\%)$} & \multicolumn{4}{|c|}{6.76} & \multicolumn{4}{|c|}{15.46} \\
\hline & \multicolumn{3}{|c|}{ Times } & Average & \multicolumn{3}{|c|}{ Times } & Ayerage \\
\hline \multirow{2}{*}{ Treatments } & Ensilage & 28 days & 56 days & Hreiage & Ensilage & 28 days & 56 days & Average \\
\hline & \multicolumn{4}{|c|}{$\mathrm{pH}$} & \multicolumn{4}{|c|}{$\mathrm{NH}_{3}-\mathrm{N}(\%$ total nitrogen $)$} \\
\hline Bagasse & $5.40 \mathrm{abA}$ & $4.63 \mathrm{aB}$ & $4.29 b C$ & 4.77 & $1.67 \mathrm{cB}$ & $2.10 \mathrm{cB}$ & $10.48 \mathrm{bA}$ & 4.75 \\
\hline Bagasse + corn & $5.27 \mathrm{bA}$ & $4.08 \mathrm{bB}$ & $3.79 \mathrm{cC}$ & 4.38 & $0.87 \mathrm{cB}$ & $1.09 \mathrm{cB}$ & $10.07 \mathrm{bA}$ & 4.01 \\
\hline Bagasse+soybean & $5.61 \mathrm{aA}$ & $4.85 \mathrm{aB}$ & $4.80 \mathrm{aB}$ & 5.09 & $3.96 \mathrm{bB}$ & $4.97 \mathrm{bAB}$ & $5.30 \mathrm{cA}$ & 4.75 \\
\hline Bagasse+rice & $5.68 \mathrm{aA}$ & $3.96 \mathrm{bB}$ & $3.77 \mathrm{cB}$ & 4.47 & $8.52 \mathrm{aC}$ & $10.69 \mathrm{aB}$ & $16.66 \mathrm{aA}$ & 11.96 \\
\hline Average & 5.49 & 4.38 & 4.17 & & 3.76 & 4.71 & 10.63 & \\
\hline CV1 $(\%)$ & \multicolumn{4}{|c|}{26.51} & \multicolumn{4}{|c|}{56.91} \\
\hline CV2 (\%) & \multicolumn{4}{|c|}{14.00} & \multicolumn{4}{|c|}{42.47} \\
\hline
\end{tabular}

Averages followed by the same small letter in the column and capital letter in the line do not differ by Tukey's test (5\%); CV1 coefficient of variation of silages; CV2 - coefficient of variation of the times.

The losses of DM are due to the occurrence of gas production during anaerobic fermentation. Particularly, fermentation by clostridia leads to considerable DM losses, attributed to $\mathrm{CO}_{2}$ formation involving decarboxylation and/or oxidation (McDONALD et al., 1991). To maximize the lactic fermentation, techniques and/or products must be used that avoid the effect of the low DM level of the material to be ensiled.

All treatments presented a $\mathrm{pH}$ reduction during fermentation, but only in the bagasse and corn grain silage did the $\mathrm{pH}$ reduction persist after fermentation for 28 days (Table 2). The highest $\mathrm{NH}_{3}-\mathrm{N}$ levels were observed in the treatments with the addition of rice bran to the bagasse, even before the beginning of the fermentation process.
The silages with added corn grain and rice meal had lower $\mathrm{pH}$ values after both fermentation periods, and only the addition of corn bran to bagasse did not exceed the upper limit suggested by McDonald et al. (1991) for the adequate preservation of feed, which is $\mathrm{pH}$ 4.2. The $\mathrm{pH}$ decline in corn silage (Table 2) is explained by the non-structural carbohydrates present in corn, which can be partially used as a substrate for anaerobic fermentation, contributing to the production of organic acids and the reduction of $\mathrm{pH}$.

The persistent high $\mathrm{pH}$ values, meant they did not reach those recommended by McDonald et al. (1991) for a suitable fermentation. This outcome is attributed to the high amount of phenolic compounds present in the olive bagasse (NIAOUNAKIS; HALVADAKIS, 2006), which increase the buffering 
capacity of the material to be ensiled (McDONALD et al., 1991) and inhibit the action of LAB during fermentative processes in the silos (RIDWAN et al., 2015). However, the moderate inclusion of olive bagasse in ruminant diets $\left(100 \mathrm{~g} \mathrm{~kg}^{-1} \mathrm{DM}\right)$ may be an advantage for reducing methane gas emissions (KONDO et al., 2014).

The slight decrease in $\mathrm{pH}$ values of bagasse silage after 28 days may be related to the increased humidity in the absence of additives, which may have favored the development of microorganisms of the genus Clostridium, responsible for the production of acetic acid (McDONALD et al., 1991). The remarkably high $\mathrm{NH}_{3}-\mathrm{N}$ values observed in the silage containing rice bran (Table 2) derive from the heat treatment that the rice undergoes during its processing to obtain the bran, which causes denaturation of proteins and accompanying release of non-protein constituents, quantified by $\mathrm{NH}_{3}-\mathrm{N}$ analysis.
The increase in the $\mathrm{NH}_{3}-\mathrm{N} / \mathrm{TN}$ throughout the fermentation for all the silages reveals that protein was degraded inside the silos with the concurrent release of nitrogen compounds. The formation of this alkali $\left(\mathrm{NH}_{3}-\mathrm{N}\right)$ contributes to the increase in $\mathrm{pH}$, inhibiting the development of undesirable microorganisms, mainly yeasts (ALLI et al., 1983). These alterations result from the action of proteolytic bacteria that act in high humidity conditions, at $\mathrm{pH}$ above 4.5 , and temperatures between 20 and $45{ }^{\circ} \mathrm{C}$. According to McDonald et al. (1991), protein hydrolysis can increase the non-protein nitrogen by up to approximately $70 \%$ of the TN in the silo opening.

Regarding the microbiological profile of the mixtures and influence of storage, the $\mathrm{LAB}$ and filamentous fungi populations were significantly changed only as a function of the sampling times, so that it was superior in the silages exposed to 56 days of fermentation (Table 3).

Table 3. Microbiological profile of olive bagasse silages with feed additives in ensilage and at 28 and 56 days of storage. Values expressed as $\log _{10}$ colony-forming units (CFU) per gram of dry matter (DM) of silage.

\begin{tabular}{|c|c|c|c|c|c|c|c|c|}
\hline \multirow{2}{*}{ Treatments } & Ensilage & 28 days & 56 days & Average & Ensilage & 28 days & 56 days & Average \\
\hline & \multicolumn{4}{|c|}{ Lactic acid bacteria $\left(\log _{10} \mathrm{CFU} \mathrm{g}^{-1} \mathrm{DM}\right)$} & \multicolumn{4}{|c|}{ Filamentous fungi $\left(\log _{10} \mathrm{CFU} \mathrm{g}^{-1} \mathrm{DM}\right)$} \\
\hline Bagasse & 0.51 & 8.14 & 9.39 & $6.01 \mathrm{a}$ & 0.50 & 7.28 & 9.21 & $5.66 \mathrm{a}$ \\
\hline Bagasse + corn & 0.46 & 8.15 & 9.03 & $5.88 \mathrm{a}$ & 1.75 & 7.09 & 9.11 & $5.98 \mathrm{a}$ \\
\hline Bagasse+soybean & 0.49 & 8.08 & 9.47 & $6.01 \mathrm{a}$ & 0.49 & 8.10 & 9.63 & $6.07 \mathrm{a}$ \\
\hline Bagasse+rice & 0.44 & 7.89 & 9.58 & $5.97 \mathrm{a}$ & 0.48 & 7.85 & 9.09 & $5.81 \mathrm{a}$ \\
\hline Average & $0.48 \mathrm{C}$ & $8.07 \mathrm{~B}$ & $9.37 \mathrm{~A}$ & & $0.80 \mathrm{C}$ & $7.58 \mathrm{~B}$ & $9.26 \mathrm{~A}$ & \\
\hline CV1 $(\%)$ & \multicolumn{4}{|c|}{13.08} & \multicolumn{4}{|c|}{22.94} \\
\hline \multirow[t]{2}{*}{ CV2 (\%) } & \multicolumn{4}{|c|}{8.58} & \multicolumn{4}{|c|}{14.60} \\
\hline & \multicolumn{3}{|c|}{ Times } & Ayerage & \multicolumn{3}{|c|}{ Times } & Average \\
\hline \multirow{2}{*}{ Treatments } & Ensilage & 28 days & 56 days & Aver & Ensilage & 28 days & 56 days & Average \\
\hline & \multicolumn{4}{|c|}{ Clostridia $\left(\log _{10} \mathrm{CFU} \mathrm{g}^{-1} \mathrm{DM}\right)$} & \multicolumn{4}{|c|}{ Enterobacteria $\left(\log _{10} \mathrm{CFU} \mathrm{g}^{-1} \mathrm{DM}\right)$} \\
\hline Bagasse & 0.51 & 7.69 & 9.41 & $5.87 \mathrm{a}$ & $0.51 \mathrm{aB}$ & 7.79aA & $8.13 \mathrm{bA}$ & 5.48 \\
\hline Bagasse + corn & 0.46 & 8.17 & 9.05 & $5.89 \mathrm{a}$ & $0.46 \mathrm{aB}$ & $7.75 \mathrm{aA}$ & $8.37 \mathrm{bA}$ & 5.53 \\
\hline Bagasse + soybean & 1.49 & 7.61 & 9.89 & $6.33 \mathrm{a}$ & $0.49 \mathrm{aC}$ & $8.18 \mathrm{aB}$ & $9.55 \mathrm{aA}$ & 6.07 \\
\hline Bagasse+rice & 0.44 & 8.21 & 9.62 & $6.09 \mathrm{a}$ & $0.44 \mathrm{aC}$ & $7.96 \mathrm{aB}$ & $9.78 \mathrm{aA}$ & 6.06 \\
\hline Media & $0.73 \mathrm{C}$ & $7.92 \mathrm{~B}$ & $9.49 \mathrm{~A}$ & & 0.48 & 7.92 & 8.96 & \\
\hline CV1 $(\%)$ & \multicolumn{4}{|c|}{20.59} & \multicolumn{4}{|c|}{15.78} \\
\hline CV2 (\%) & \multicolumn{4}{|c|}{12.83} & \multicolumn{4}{|c|}{9.13} \\
\hline
\end{tabular}

Averages followed by the same small letter in the column and capital letter in the line do not differ by Tukey's test (5\%); CV1 coefficient of variation of silages; CV2 - coefficient of variation of the times. 
The population of clostridia was comparable with that of the LAB, with significance only for the fermentation times, revealing a greater population in the silages with 56 days of anaerobic storage (Table 3). There was a significant interaction between the factors studied when comparing the enterobacteria populations, with a higher population in the mixtures of olive bagasse with rice and soybean bran, and in these blends at 56 days of fermentation. The increased DM of the combinations reduces the possibilities of losses by effluents and the development of bacteria of the genus Clostridium (McDONALD et al., 1991) that cause negative impacts on the feeding value (OLADOSU et al., 2016) by promoting undesirable secondary fermentations and the formation of butyric acid (McDONALD et al., 1991). Many species of the Clostridium genus are capable of saccharolytic and proteolytic (breaking down carbohydrate and protein, respectively) activities. Clostridium bifermentans and C. sporogenes are extremely proteolytic. Conversely, $C$. butyricum and C. tyrobutyricum are mildly proteolytic, so when these two species predominate in the Clostridium population, although the clostridia count may be high, the proteolytic activity and $\mathrm{N}-\mathrm{NH}_{3}$ production may be mild.

At 28 days of fermentation, all silages presented statistically similar populations of enterobacteria, with an average of $7.92 \log _{10} \mathrm{CFU} \mathrm{g} \mathrm{g}^{-1} \mathrm{DM}$. When considering the sampling times, the factors evaluated showed a significant interaction for the enterobacteria population (Table 3). At 56 days of storage, the enterobacteria population decreased when maize was used as the additive, but the use of rice and soybean brans had the opposite trend (Table 3).

The low population of bacteria involved in the homofermentative process, such as LAB, which rapidly reduce the $\mathrm{pH}$ of the silage at the beginning of the fermentation process, avoids the development and undesirable fermentations caused by clostridia microorganisms and enterobacteria.
Therefore, the low growth of microorganisms of the genus Clostridium is desirable since they are the main microorganisms that deteriorate the silages (MOTA et al., 2011). The DM contents of the treatments and the high content of polyphenols present in the olive bagasse were important for this low development because polyphenols act as a barrier to the microbial development of clostridia (NIAOUNAKIS; HALVADAKIS, 2006). However, the maintenance of a saccharolytic clostridia population is owed to their ability to ferment sugar and lactic acid, producing hydrogen, $\mathrm{CO}_{2}$ and butyric acid (OLADOSU et al., 2016). This process may not drastically alter the $\mathrm{pH}$, but it maintains the total clostridia count of the silage.

The LAB, which exhibited similar populations in all silages, use amino acids as a source of energy for growth and release ammonia inside the silos, consequently increasing the amount of $\mathrm{NH}_{3}-\mathrm{N}$ during fermentation (BERNARDES et al., 2005).

The enterobacteria belong to the group of epiphytic microbiota found on feeds, mainly forages (OLADOSU et al., 2016). These bacteria maintained their population throughout the fermentation, in all silages studied (Table 3 ) because they are facultative anaerobes (MUCK, 2010). Larger populations were observed in the silages with added soybean and rice brans than the other treatments (Table 3), as these two additives increased the $\mathrm{CP}$ of the silages. Enterobacteria have weak proteolytic activities and can decarboxylate and deaminate some amino acids (OLADOSU et al., 2016). Also, various species of enterobacteria can use nitrate as an electron acceptor in place of oxygen, reducing nitrate to nitrite or nitrogen oxide (MUCK, 2010).

The MM content of the mixtures and the storage time were affected by the interaction of the studied factors, revealing a higher content of MM in the mixtures with rice bran (Table 4). Whereas the MM content was not altered by the corn and soybean bran additives, it was reduced in the absence of additives, during fermentation. Throughout the 
storage process, the production of effluents causes a proportional increase in organic matter and a reduction in MM. The treatment with corn grain presented the lowest levels of MM when compared to the other treatments (Table 4), owing to its chemical composition (Table 1).

Table 4. Chemical composition profile of olive bagasse silages with feed additives at ensilage and 28 and 56 days of storage.

\begin{tabular}{|c|c|c|c|c|c|c|c|c|}
\hline \multirow{2}{*}{ Treatments } & Ensilage & 28 days & 56 days & Average & Ensilage & 28 days & 56 days & Average \\
\hline & \multicolumn{4}{|c|}{ Mineral matter $\left(\mathrm{g} \mathrm{kg}^{-1} \mathrm{DM}\right)$} & \multicolumn{4}{|c|}{ Ether extract $\left(\mathrm{g} \mathrm{kg}^{-1} \mathrm{DM}\right)$} \\
\hline Bagasse & $54.61 \mathrm{bA}$ & $39.45 \mathrm{bB}$ & $35.69 \mathrm{cB}$ & 43.25 & $235.72 \mathrm{aB}$ & $251.55 \mathrm{aB}$ & $301.28 \mathrm{aA}$ & 262.85 \\
\hline Bagasse + corn & $31.62 \mathrm{dA}$ & $30.73 \mathrm{cA}$ & $29.98 \mathrm{cA}$ & 30.78 & $188.96 \mathrm{bB}$ & $207.24 \mathrm{bAB}$ & $224.97 \mathrm{bA}$ & 207.06 \\
\hline Bagasse+soybean & $47.03 \mathrm{cA}$ & $46.78 \mathrm{aA}$ & $43.66 \mathrm{bA}$ & 45.83 & $213.36 \mathrm{abA}$ & $197.20 \mathrm{bA}$ & $220.99 \mathrm{bA}$ & 210.52 \\
\hline Bagasse+rice & $70.76 \mathrm{aA}$ & $47.70 \mathrm{aC}$ & $56.50 \mathrm{aB}$ & 58.32 & $238.05 \mathrm{aA}$ & $198.28 \mathrm{bB}$ & $194.48 \mathrm{bB}$ & 210.27 \\
\hline Average & 51.01 & 41.17 & 41.46 & & 219.02 & 213.57 & 235.43 & \\
\hline CV1 $(\%)$ & \multicolumn{4}{|c|}{8.55} & \multicolumn{4}{|c|}{6.87} \\
\hline \multirow[t]{2}{*}{ CV2 (\%) } & \multicolumn{4}{|c|}{9.38} & \multicolumn{4}{|c|}{9.16} \\
\hline & \multicolumn{3}{|c|}{ Times } & & \multicolumn{3}{|c|}{ Times } & \\
\hline \multirow{2}{*}{ Treatments } & Ensilage & 28 days & 56 days & A & Ensilage & 28 days & 56 days & Averas \\
\hline & \multicolumn{4}{|c|}{ Crude protein $\left(\mathrm{g} \mathrm{kg}^{-1} \mathrm{DM}\right)$} & \multicolumn{4}{|c|}{ Neutral detergent fiber $\left(\mathrm{g} \mathrm{kg}^{-1} \mathrm{DM}\right)$} \\
\hline Bagasse & $111.70 \mathrm{bA}$ & $65.60 \mathrm{bcB}$ & $63.14 \mathrm{cB}$ & 80.15 & 593.15 & 640.84 & 687.20 & $640.40 \mathrm{ab}$ \\
\hline Bagasse + corn & $56.50 \mathrm{cA}$ & $55.68 \mathrm{cA}$ & $60.45 \mathrm{cA}$ & 57.55 & 590.17 & 659.39 & 673.08 & $640.88 \mathrm{ab}$ \\
\hline Bagasse+soybean & $166.72 \mathrm{aA}$ & $170.34 \mathrm{aA}$ & $166.15 \mathrm{aA}$ & 167.74 & 564.93 & 655.67 & 671.97 & $630.86 b$ \\
\hline Bagasse+rice & $117.46 \mathrm{bA}$ & $85.97 \mathrm{bB}$ & $93.78 \mathrm{bB}$ & 99.07 & 575.72 & 694.36 & 729.08 & $666.39 \mathrm{a}$ \\
\hline Average & 113.10 & 94.40 & 95.88 & & $580.99 \mathrm{C}$ & $662.57 \mathrm{~B}$ & $690.33 \mathrm{~A}$ & \\
\hline CV1 (\%) & \multicolumn{4}{|c|}{14.69} & \multicolumn{4}{|c|}{5.59} \\
\hline CV2 $(\%)$ & \multicolumn{4}{|c|}{12.21} & \multicolumn{4}{|c|}{5.33} \\
\hline \multirow{2}{*}{ Treatments } & Ensilage & 28 days & 56 days & Average & Ensilage & 28 days & 56 days & Average \\
\hline & \multicolumn{4}{|c|}{ Acid detergent fiber $\left(\mathrm{g} \mathrm{kg}^{-1} \mathrm{DM}\right)$} & \multicolumn{4}{|c|}{ Hemicellulose $\left(\mathrm{g} \mathrm{kg}^{-1} \mathrm{DM}\right)$} \\
\hline Bagasse & $405.87 \mathrm{aB}$ & $597.77 \mathrm{aA}$ & $599.41 \mathrm{aA}$ & 534.35 & $187.28 \mathrm{aA}$ & $43.07 \mathrm{bB}$ & $87.79 \mathrm{bB}$ & 106.05 \\
\hline Bagasse + corn & $425.91 \mathrm{aC}$ & $498.33 \mathrm{bB}$ & $569.28 \mathrm{abA}$ & 497.84 & $164.26 \mathrm{aA}$ & $161.06 \mathrm{aA}$ & $103.80 \mathrm{abA}$ & 143.04 \\
\hline Bagasse+soybean & $343.06 \mathrm{bB}$ & $483.49 \mathrm{bA}$ & $513.13 \mathrm{cA}$ & 446.56 & $221.86 \mathrm{aA}$ & $172.18 \mathrm{aA}$ & $158.84 \mathrm{abA}$ & 184.29 \\
\hline Bagasse+rice & $401.64 \mathrm{aC}$ & $497.94 \mathrm{bB}$ & $553.61 \mathrm{bcA}$ & 484.40 & $174.08 \mathrm{aA}$ & $196.42 \mathrm{aA}$ & $175.47 \mathrm{aA}$ & 181.99 \\
\hline Average & 394.12 & 519.38 & 558.86 & & 186.87 & 143.18 & 131.48 & \\
\hline CV1 (\%) & \multicolumn{4}{|c|}{5.16} & \multicolumn{4}{|c|}{31.63} \\
\hline \multirow[t]{2}{*}{ CV2 (\%) } & \multicolumn{4}{|c|}{4.85} & \multicolumn{4}{|c|}{29.31} \\
\hline & \multicolumn{3}{|c|}{ Times } & & & Tim & & \\
\hline & Ensilage & 28 days & 56 days & A & Ensilage & 28 days & 56 days & e \\
\hline $\mathrm{Tr}$ & & Cellulose ( & $\left.\mathrm{kg}^{-1} \mathrm{DM}\right)$ & & & Lignin ( $\mathrm{g} \mathrm{l}$ & $\left.\mathrm{g}^{-1} \mathrm{DM}\right)$ & \\
\hline Bagasse & $114.00 \mathrm{bB}$ & $159.21 \mathrm{bA}$ & $163.51 \mathrm{bA}$ & 145.58 & $316.43 \mathrm{aC}$ & $364.57 \mathrm{aB}$ & $408.91 \mathrm{aA}$ & 363.30 \\
\hline Bagasse + corn & $155.67 \mathrm{aA}$ & $100.10 \mathrm{cB}$ & $155.82 \mathrm{bA}$ & 137.20 & $271.67 \mathrm{bB}$ & $354.75 \mathrm{abA}$ & $354.34 \mathrm{bcA}$ & 326.92 \\
\hline Bagasse+soybean & $76.62 \mathrm{cB}$ & $242.64 \mathrm{aA}$ & $234.72 \mathrm{aA}$ & 184.66 & $234.68 b C$ & $320.40 \mathrm{bB}$ & $385.41 \mathrm{abA}$ & 313.50 \\
\hline Bagasse+rice & $80.45 \mathrm{cB}$ & $213.68 \mathrm{aA}$ & $226.35 \mathrm{aA}$ & 173.50 & $266.48 \mathrm{bB}$ & $341.84 \mathrm{abA}$ & $323.59 \mathrm{cA}$ & 310.64 \\
\hline Average & 106.69 & 178.91 & 195.10 & & 272.31 & 345.39 & 368.06 & \\
\hline CV1 $(\%)$ & & 16 & & & & 5.8 & & \\
\hline CV2 (\%) & & 12 & & & & 6.8 & & \\
\hline
\end{tabular}

Averages followed by the same small letter in the column and capital letter in the line do not differ by Tukey's test ( $5 \%$ ); DM - dry matter; CV1 - coefficient of variation of silages; CV2 - coefficient of variation of the times. 
The content of MM obtained in the silage with added rice bran is justified by its composition, which traditionally comprises high levels of MM and silica (VALADARES FILHO et al., 2008). The MM levels of in natura bagasse silage are consistent with those reported by Nefzaoui (1991). When rice bran was used as an additive, the MM quantity was lowered at 28 days of fermentation and intermediate at 56 days relative to the amount before fermentation. This result is expected, given the production of effluents, which contain minerals present in the ensilaged material (McDONALD et al., 1991), and to the fermentative losses, which favor the consumption of carbohydrates, especially structural carbohydrates, altering the concentration of the other nutrients in the total DM stored in the silos.

The EE of the bagasse decreased significantly when corn and soybean brans were added on the day of ensiling, although, only rice bran treatment significantly reduced the EE content during fermentation. Olive bagasse showed the highest EE content at 56 days of fermentation (Table 4). High levels of EE are directly related to the total digestible nutrient values of feed; however, it is necessary to evaluate and account for digestible EE. The high ADF in olive bagasse (Table 4) ultimately confers a low digestibility to this sub-product. Thus, the high EE and ADF contents of olive bagasse are the two main factors limiting its use at high inclusion levels in ruminant feed.

The use of the additives favored the dilution of EE in relation to in natura silage (Table 4). Niaounakis and Halvadakis (2006) cited the EE content of olive bagasse (essentially lipids and polyphenols) as a positive attribute for the preservation of the ensiled mass, by acting to impede the anaerobic degradation of the substrate. The fatty substances in bagasse are very rich in saturated $\mathrm{C}_{16}$ and $\mathrm{C}_{18}$ fatty acids, contributing to $96 \%$ of the total fatty acids, and can be a significant source of energy (SANSOUCY et al., 1985).
The $\mathrm{CP}$ was reduced with the addition of corn bran to the olive bagasse while the addition of soybean and rice bran increased the $\mathrm{CP}$ contents of the silages (Table 4). The NDF was significantly altered only by the sampling times studied, presenting an increase over the ensiling period (Table 4). There was an interaction effect of the factors examined in regards to the ADF content, which was decreased by the addition of soybean bran to the bagasse (Table 4).

The decrease in CP by the inclusion of corn bran and the increase observed when adding soybean bran and rice reflect the $\mathrm{CP}$ present in these brans, which have an average $\mathrm{CP}$ content of 87,450 and $126 \mathrm{~g} \mathrm{~kg}^{-1}$ respectively (Table 1). After fermentation, only the silages with soybean and rice reached the minimum CP content of $70 \mathrm{~g} \mathrm{~kg}^{-1}$ proposed by Van Soest (1994) as the lower limit for survival and multiplication of microorganisms in the ruminal environment. These results suggest the addition of these brans as a promising option for improving the $\mathrm{CP}$ contents of the olive bagasse silage.

As the fermentation evolved, the CP contents remained unchanged (corn and soybean bran silages) or decreased (in natura bagasse and rice bran silage) (Table 4). These changes characterize the occurrence of fermentative processes inside the silos that caused losses of nitrogenous compounds, by leaching as effluent or volatilization of the volatile compounds formed (McDONALD et al., 1991).

The NDF comprises lignin, hemicellulose and cellulose, and is the most common parameter used for balancing of ruminant diets. Lignin is insoluble in the absence of chemical treatments and is intricately complexed with hemicellulose and cellulose in the plant cell walls (SILVA; QUEIROZ, 2009), so these constituents are largely maintained during fermentation processes. The increase NDF observed in this study is related to the fermentation time, as the fermentation degradative reactions, production of effluents and losses of nitrogen 
compounds, cause a proportional increase in the fractions of the fibrous carbohydrates in the ensiled DM (NERES et al., 2013).

The ADF is composed by cellulose and lignin and indicates the amount of indigestible material (lignin) or slow digestion at the ruminal (cellulose) level (VAN SOEST, 1994). The ADF fraction of the silages increased (Table 4), due to the losses that occurred during the fermentation, having a nonbeneficial impact on the nutritional quality of the olive bagasse.

The hemicellulose was lower in the olive bagasse silage at 28 and 56 days of fermentation than the mixtures with additives, in which the hemicellulose content largely remained constant (Table 4). Xylan is the most common hemicellulosic material in the plant cell walls (SARATALE et al., 2012). Owing to its structurally mixed composition, degradation of the substrate to its monomer, xylose, requires specialized xylanolytic enzyme systems, possessing different modes of action and specificities. These enzymes are secreted by ruminal microorganisms (VAN SOEST, 1994) and by filamentous fungi (BISWAS et al., 2010), and their action is nutritionally positive, as they promote xylan hydrolysis, facilitating subsequent microbial digestion in the rumen (MARTINS et al., 2007). Hence, the action of xylanases accounts for the observed changes in the hemicellulose contents of the silages.

There was a significant effect of the interaction of the studied factors on the cellulose contents (Table 4). Cellulose is the most abundant, homogenous and recalcitrant carbohydrate fraction of the plant cell wall, and is composed of long linear chains of high molecular weight D-glucopyranoses and a high degree of polymerization (GIGER-REVERDIN, 1995). The recalcitrance of cellulose to enzymatic hydrolysis by ensilage and ruminal fermentation microorganisms is due to the extensive hydrogen bonding interactions of individual cellulose strands, forming cellulose microfibrils with an inner crystalline core that is impenetrable to water. Furthermore, in the plant cell wall, the cellulose microfibrils are embedded in a matrix of hemicellulose and lignin (VAN SOEST, 1994).

Olive bagasse is characterized by high contents of lignin and lignocellulosic compounds (DERMECHE et al., 2013), and its cellulose is highly associated with the xylans and other polysaccharides, such as arabinose and galactose (NIAOUNAKIS; HALVADAKIS, 2006). Hence, the biochemical processes occurring inside the silos with additives are critical to providing a rational approach to using the olive bagasse co-product at the ruminal level.

The lignin contents were reduced in treatments with additives (Table 4). Therefore, the decrease in this phenolic-containing compound, which is considered to be the most harmful to the fermentation processes inside the rumen, suggests the possibility of better utilization of the fermentable carbohydrates present in the olive bagasse (DERMECHE et al., 2013).

\section{Conclusions}

The use of corn grain improved the fermentation characteristics of the olive bagasse silage. Corn, rice and soybean meal can be used as additives in the ensilage of olive bagasse to increase the DM content, but only the rice and soybean meal benefited the chemical composition profile of the silages. The meals used are recommended for use in olive bagasse silage, although, the choice of the additives studied will depend on the commercial availability in each region.

Increasing the storage period reduced the $\mathrm{pH}$ of the silages, but increased the losses of $\mathrm{DM}$ and $\mathrm{NH}_{3}-\mathrm{N}$, and contributed to the losses of some nutrients. Hence, 28 days of storage was recommended for the studied silages. Ensilaged olive bagasse can be used in the diet of ruminants, considering its chemical composition. The inclusion levels in the 
feed offered to ruminants, should consider the animal's requirement, limits of different nutrients and, particularly, the EE and ADF contents of the olive bagasse co-products.

\section{References}

ABAZI, U.; LORITE, I. J.; CÁRCELES, B.; MARTÍNEZ RAYA, A.; DURÁN, V. H.; FRANCIA, J. R.; GÓMEZ, J. A. WABOL: a conceptual water balance model for analyzing rainfall water use in olive orchards under different soil and cover crop management strategies. Computers and Electronics in Agriculture, Amsterdam, v. 91, n. 1, p. 35-48, 2013. DOI: /10.1016/j. compag.2012.11.010

ALLI, I.; FAIRBAIRN, R.; BAKER, B. E.; GARCIA, G. The effects of ammonia on the fermentation of chopped sugarcane. Animal Feed Science and Technology, Amsterdam, v. 9, n. 4, p. 291-299, 1983. DOI: 10.1016/0377-8401(83)90022-6

AZEVÊDO, J. A. G.; VALADARES FILHO, S. C.; PINA, D. S.; DETMANN, E.; VALADARES, R. F. D.; PEREIRA, L. G. R.; SOUZA, N. K. P.; COSTA E SILVA, L. F. Consumo, digestibilidade total, produção de proteína microbiana e balanço de nitrogênio em dietas com subprodutos de frutas para ruminantes. Revista Brasileira de Zootecnia, Viçosa, MG, v. 40, n. 5, p. 10521060, 2011.

BERNARDES, T. F.; REIS, R. A.; MOREIRA, A. L. Fermentative and microbiological profile of Marandugrass ensiled with citrus pulp pellets. Scientia Agricola, Piracicaba, v. 62, n. 3, p. 214-220, 2005. DOI: 10.1590/ S0103-90162005000300003

BISWAS, R.; SAHAI, V.; MISHRA, S.; BISARIA, V. S. Bioprocess strategies for enhanced production of xylanase by Melanocarpus albomyces IITD3A on agro-residual extract. Journal of Bioscience and Bioengineering, Amsterdam, v. 110, n. 6, p. 702-708, 2010. DOI: $10.1016 /$ j.jbiosc.2010.07.013

BOLSEN, K. K.; LIN, C.; BRENT, B. E.; FEYERHERM, A. M.; URBAN, J. E.; AIMUTIS, W. R. Effect of silage additives on the microbial succession and fermentation process of alfalfa and corn silages. Journal of Dairy Science, Knoxville, v. 75, n. 11, p. 3066-3083, 1992. DOI: $10.3168 /$ jds.S0022-0302(92)78070-9

CHIOFALO, B.; LIOTTA, L.; ZUMBO, A.; CHIOFALO, $\mathrm{V}$. Administration of olive cake for ewe feeding: effect on milk yield and composition. Small Ruminant Research, Amsterdam, v. 55, n. 1-3, p. 169-176, 2004. DOI: 10.1016/j.smallrumres.2003.12.011
DERMECHE, S.; NADOUR, M.; LARROCHE, C.; MOULTI-MATI, F.; MICHAUD, P. Olive mill wastes: biochemical characterizations and valorization strategies. Process Biochemistry, Amsterdam, v. 48, n. 10, p. 15321552, 2013. DOI: $10.1016 /$ j.procbio.2013.07.010

FERREIRA, D. F. Sisvar: a computer statistical analysis system. Ciência e Agrotecnologia, Lavras, v. 35, n. 6, p. 1039-1042, 2011. DOI: 10.1590/S141370542011000600001

GIGER-REVERDIN, S. Review of the main methods of cell wall estimation: interest and limits for ruminants. Animal Feed Science and Technology, Amsterdam, v. 55, n. 3-4, p. 295-334, 1995. DOI: 10.1016/03778401(95)00791-K

GONÇALVES, J. A. G.; ZAMBOM, M. A.; FERNANDES, T.; MESQUITA, E. E.; SCHIMIDT, E.; JAVORSKI, C. R.; CASTAGNARA, D. D. Composição químico-bromatológica e perfil de fermentação da silagem de resíduo úmido de fécula de mandioca. Bioscience Journal, Uberlandia, v. 30, n. 2, p. 502-511, 2014.

KONDO, M.; HIRANO, Y.; KITA, K.; JAYANEGARA, A.; YOKOTA, H.-O. Fermentation characteristics, tannin contents and in vitro ruminal degradation of green tea and black tea by-products ensiled at different temperatures. Asian Australasian Journal of Animal Sciences, Gwanak-gu, v. 27, n. 7, p. 937-945, 2014. DOI: 10.5713/ajas.2013.13387

MARTINS, A. S.; VIEIRA P. F.; BERCHIELLI, T. T.; PRADO, I. N.; LEMPP, B.; PAULA, M. C. Degradabilidade in situ e observações microscópicas de volumosos em bovinos suplementados com enzimas fibrolíticas exógenas. Revista Brasileira de Zootecnia, Viçosa, MG, v. 36, n. 6, p. 1927-1936, 2007.

McDONALD, P.; HENDERSON, A. R.; HERON, S. J. E. The biochemistry of silage. $2^{\text {th }}$ ed. Marlou: Chalcombe Publications, 1991. $340 \mathrm{p}$.

MOLINA-ALCAIDE, E.; YAÑEZ-RUIZ, D. R. Potential use of olive by-products in ruminant feeding: a review. Animal Feed Science and Technology, Amsterdam, v. 147 , n. $1-3$, p. $247-264,2008$. DOI: $10.1016 / \mathrm{j}$. anifeedsci.2007.09.021

MOTA, Á. D. S.; ROCHA JÚNIOR, V. R.; SOUZA, A. S.; REIS, S. T.; TOMICH, T. R.; CALDEIRA, L. A.; MenezeS, G. C. C.; COSTA, M. D. Perfil de fermentação e perdas na ensilagem de diferentes frações da parte aérea de quatro variedades de mandioca. Revista Brasileira de Zootecnia, Viçosa, MG, v. 40, n. 7, p. 14661473, 2011. 
MUCK, R. E. Silage microbiology and its control through additives. Revista Brasileira de Zootecnia, Viçosa, MG, v. 39, n. 1, p. 183-191, 2010. DOI: 10.1590/S151635982010001300021

NASOPOULOU, C.; ZABETAKIS, I. Agricultural and aquacultural potential of olive pomace: a review. Journal of Agricultural Science, Toronto, v. 5, n. 7, p. 116-127, 2013.

NEFZAOUI, A. Valorisation des sous-produits de l'olivier. Options Méditerranéennes, TunisiaTúnisia, v. 1, n. 16, p. 101-108, 1991.

NERES, M. A.; ZAMBOM, M. A.; FERNANDES, T.; CASTAGNARA, D. D.; RODRIGUES, J. F. H.; TAFFAREL, L. E.; JAVORSKI, C. R.; POZZA, M. S. S. Microbiological profile and aerobic stability of Tifton 85 bermudagrass silage with different additives. Revista Brasileira de Zootecnia, Viçosa, MG, v. 42, n. 6, p. 381387, 2013. DOI: 10.1590/S1516-35982013000600001

NIAOUNAKIS, M.; HALVADAKIS, C. P. Olive processing waste management literature review and patent survey. $2^{\text {th }}$ ed. Amsterdam: Elsevier, 2006. 498 p. (Waste Management series, 5).

OLADOSU, Y.; RAFII, M. Y.; ABDULLAH, N.; MAGAJI, U.; HUSSIN, G.; RAMLI, A.; MIAH, G. Fermentation quality and additives: a case of rice straw silage. BioMed Research International, London, v. 2016, article no. 7985167, p. 14, 2016. DOI: $10.1155 / 2016 / 7985167$

RIDWAN, R.; RUSMANA, I.; WIDYASTUTI, Y.; WIRYAWAN, K. G.; PRASETYA, B.; SAKAMOTO, M.; OHKUMA, M. Fermentation characteristics and microbial diversity of tropical grass-legumes silages. Asian-Australasian Journal of Animal Sciences, Gwanak-gu, v. 28, n. 4, p. 511-518, 2015. DOI: 10.5713/ ajas. 14.0622

SANSOUCY, R.; ALIBES, X.; BERGE, P. H.; MARTILOTTI, F.; NEFZAOUI, A.; ZOÏOPOULOS, P. Olive by-products for animal feed. Rome: FAO, 1985. (FAO animal production and health paper, 43).
SARATALE, G. D.; SARATALE, R. G.; OH, S. E. Production and characterization of multiple cellulolytic enzymes by isolated Streptomyces sp. MDS. Biomass and Bioenergy, Amsterdam, v. 47, n. 1, p. 302-315, 2012. DOI: $10.1016 /$ j.biombioe.2012.09.030

SILVA, D. J.; QUEIROZ, A. C. Análise de alimentos: métodos químicos e biológicos. $3^{\text {th }}$ ed. Viçosa, MG: Universidade Federal de Viçosa, 2009. 235 p.

SILVA, N.; JUNQUEIRA, V. C. A.; SILVEIRA, N. F. A.; TANIWAKI, M. H.; SANTOS, R. F. S.; GOMES, R. A. R.; OKAZAKI, M. M. Manual de métodos de análise microbiológica de alimentos. $3^{\text {th }}$ ed. São Paulo: Varela, 2007. $536 \mathrm{p}$.

SOUZA, L. C.; ZAMBOM, M. A.; POZZA, M. S. S.; NERES, M. A.; RADIS, A. C.; BORSATTI, L.; CASTAGNARA, D. D.; GUNDT, S. Development of microorganisms during storage of wet brewery waste under aerobic and anaerobic conditions. Revista Brasileira de Zootecnia, Viçosa, MG, v. 41, n. 1, p. 188193, 2012. DOI: 10.1590/S1516-35982012000100027

VALADARES FILHO, S. C.; MACHADO, P. A. S.; CHIZZOTTI, M. L.; AMARAL, H. F.; MAGALHÃES, K. A.; ROCHA JUNIOR, V. R.; CAPELLE, E. R. Tabelas brasileiras de composição de alimentos para bovinos. $3^{\text {th }}$ ed. Viçosa, MG: Universidade Federal de Viçosa, 2008. $502 \mathrm{p}$.

VAN SOEST, P. J. Nutritional ecology of the ruminant. $2^{\text {th }}$ ed. Ithaca: Cornell University Press, 1994. 476 p.

VAN SOEST, P. J.; ROBERTSON, J. B.; LEWIS, B. A. Methods for dietary fiber, neutral detergent fiber, and nonstarch polysaccharides in relation to animal nutrition. Journal of Dairy Science, Madison, v. 74, n. 10, p. 35833597, 1991. DOI: 10.3168/jds.S0022-0302(91)78551-2

WEINBERG, Z. G.; CHEN, Y.; WEINBERG, P. Ensiling olive cake with and without molasses for ruminant feeding. Bioresource Technology, New York, v. 99, n. 6, p. 1526-1529, 2008. DOI: 10.1016/j.biortech.2007.04.022 